\title{
Effects of Coriander Essential Oil on the Performance, Blood Characteristics, Intestinal Microbiota and Histological of Broilers
}

-Author(s)

\section{Ghazanfari S \\ Mohammadi Z' \\ Adib Moradi M"}

Department of Animal and Poultry Sciences, University of Tehran, Aburaihan campus, Pakdasht, Tehran, Iran.

" Department of Basic Sciences, Faculty of Veterinary Medicine, University of Tehran, Tehran, Iran.

\section{Mail Address}

Corresponding author e-mail address Dr. Shokoufe Ghazanfari, Department of Animal and Poultry Sciences, University of Tehran, Aburaihan campus, Pakdasht, Tehran, Iran.

Email: shghazanfari@ut.ac.ir

\section{EKeywords}

Alternative growth promoters, antibiotics, broiler, extract, performance.

\section{ABSTRACT}

Present study was conducted to investigate the effects of the dietary supplementation of coriander oil on broiler performance, blood characteristics, microbiota, and small intestine morphology measurements. A number of one-day-old broiler chickens (Ross 308) were allocated to five treatments, with four replicates according to a completely randomized design (CRD). Birds were offered either a cornsoybean meal basal diet (control), or the basal diet supplemented with $600 \mathrm{mg} / \mathrm{kg}$ of a flavophospholipol antibiotic, 100, 200, or $300 \mathrm{mg} / \mathrm{kg}$ coriander essential oil. At 42 days of age, two birds per replicate were selected for blood collection, slaughtered, and its intestinal microbiota and morphology were investigated. The results indicated that weight gain, feed intake, and feed conversion ratio significantly improved by the dietary inclusion of the coriander oil and antibiotic compared with the control treatment $(p<0.01)$. Blood biochemistry parameters were not affected by dietary treatments ( $>0.05$ ). Birds fed the coriander oil and antibiotic diets had lower populations of Escherichia coli than control group in cecum $(p<0.05)$. The dietary treatments influenced the morphology of small intestinal villi. Birds fed antibiotic and coriander essential oil presented higher villus height and crypt depth compared with those in the control treatment $(p<0.01)$. Coriander essential oil supplementation significantly decreased epithelial thickness and the number of goblet cell of the small intestinal compared with the control treatment $(p<0.0001)$. In conclusion, coriander oil was shown to be an efficient growth promoter. The intestinal health improvement obtained with coriander oil was associated with improvements in broiler growth performance.

\section{INTRODUCTION}

Modern intensive poultry production has achieved phenomenal improvements, resulting in the efficient and economical production of high quality and safe chicken meat and eggs. The use of feed additives has been an important part of achieving this success. Common feed additives used in poultry diets include antimicrobials and antioxidants (Hashemi et al., 2012). Phytogenics are a relatively new class of feed additives. Evidences suggest that some herbal plants have appetitestimulating properties, anti-bacterial effects, or may have antioxidant functions (Mountzouris et al., 2007). It has been reported that essential oils improved poultry growth performance because of their ability to increase dietary digestibility (Jamroz et al., 2005; Cross et al., 2007), to balance the gut microbial ecosystem, improving gut health (Hong et al., 2012), and to stimulate the secretion of endogenous digestive enzymes (Williams \& Losa, 2001; Cross et al., 2007).

Coriander (Coriander sativum) is an umbelliferous annual plant of parsley family, native of eastern Mediterranean and Southern Europe, 
and found in many other parts of the world (Ertas et al., 2005). Coriander oil is obtained by steam distillation of the dried fully ripe fruits (seeds) of Coriandrum sativum $L$ (Burdock \& Carabin, 2009). The oil is a colorless or pale yellow liquid with a characteristic odor and mild, sweet, and aromatic flavor. Coriander oil has been recognized as GRAS (generally recognized as safe) for use in foods by FDA (Food and Drug Administration) and it is approved by the Council of Europe. The main constituent of the volatile oil is the monoterpene alcohol, linalool (70\%) (Burdock \& Carabin, 2009).

Coriander has been used as a medicinal plant to manage diabetes, and as an antifungal, antioxidant hypolipidemic, antimicrobial, hypocholesterolemic and anticonvulsant compound (Delaquis et al., 2002). In addition, it stimulates appetite and digestion (Çabuk et al., 2003). Recent studies have also demonstrated it has hypoglycemic action and affects carbohydrate metabolism. The hypoglycemic effect of plants may be due to presence of insulin-like substances, stimulating $\beta$ cells to produce more insulin, improving insulin action and binding, increasing glucose metabolism, and may also have regenerative effect on the pancreatic tissue (Gholamali et al., 2007).

The antimicrobial effect of essential oils is well established in vitro against important pathogens, including fungi (Hammer et al., 1999) and in vivo against Escherichia coli and Clostridium perfringens in broilers (Jamroz et al., 2003). Regarding reported biological activities, coriander oil showed very good antibacterial activity against some human pathogenic bacteria, namely Staphylococcus aureus, Streptococcus haemolyticus, Pseu-domonas aeruginosa, Escherichia coli, and Listeria monocytogenes (Delaquis et al., 2002). Coriander has been reported to markedly reduce lipid biosynthesis and recently, to achieve protective role against the experimental colon carcinogenesis effects of some lipids (Lee et al., 2003).

In this study, we investigated the use of coriander oil compared to an antibiotic in broiler nutrition asa natural growth promoting substance on growth performance, some blood parameters, and intestinal microbiology and histological characteristics.

\section{MATERIAL AND METHODS}

\section{Animals and experimental treatments}

In this experiment, 200 one-day-old broilers (Ross 308 (were randomly allocated to five treatments with four replicates of 10 birds each (five males and five females). The birds were kept in 20 pens $(1 \times 1.1 \mathrm{~m})$.
Temperature and relative humidity was maintained within the optimal range. A lighting program of $23 \mathrm{~h}$ of light and $1 \mathrm{~h}$ of darkness was applied. Feed and water were offered ad libitum. The basal diet was in mash form and formulated for starter (1-10 days of age), grower (11-24 days of age) and finisher (25-42 days of age) rearing periods and the diet composition is shown in Table 1. The treatments consisted of control group fed the basal diet (no essential oil); three groups fed the basal diet supplemented with coriander essential oil at levels of 100, 200 or $300 \mathrm{mg} / \mathrm{kg}$ of diet; and one group fed the basal diet supplemented with $600 \mathrm{mg} /$ $\mathrm{kg}$ of a flavophospholipol ${ }^{1}$ antibiotic (recommended level for growth promotion). Treatment diets were fed during the entire experimental period (1-42 days). The coriander essential oil was mixed with a carrier (soybean oil), which was then added to the basal diet. The coriander essential oil was provided by Zardband Pharmaceutical Company (Tehran, Iran). The chemical composition of the coriander essential oil was provided by the manufacturer company as follows: linalool (67.6 $\%), \alpha$-pinene $(7.1 \%)$, camphor $(4.4 \%)$, and terpinene gamma (7.2\%).

\section{Performance Parameters}

Body weight and feed intake were determined when broilers on days 10, 24, and 42 and used to calculate growth performance parameters (weight gain, feed intake and feed conversion ratio (FCR).

\section{Blood samples}

Blood samples ( $n=8$ male birds/treatment) were obtained by puncture of the left wing vein at 42 days of age for subsequent determination of cholesterol and triglyceride serum levels. Blood samples were immediately centrifuged for $15 \mathrm{~min}$ at $3000 \mathrm{rpm}$ to obtain the serum, and serum samples were kept in conical tubes at $-20^{\circ} \mathrm{C}$ until analyses. Individual serum samples were analyzed for glucose, total cholesterol, triglyceride, high-density lipoprotein (HDL), low-density lipoprotein (LDL), and very low density lipoprotein (VLDL) cholesterol levels using commercial kits (Pars Azmoon kits, Pars Azmoon Inc., Tehran) (Toghyani et al., 2011).

\section{Enumeration of bacteria}

At 42 days of age, four male birds from each dietary treatment were randomly selected and slaughtered by decapitation. Their digestive tracts were immediately

\footnotetext{
-Flavophospholipol 0.6\%, Premix; Production Animal Drug Company; each $1 \mathrm{~kg}$ premix contains $600 \mathrm{mg}$ active flavophospholipol.
} 
Table 1 - Composition of basal diet and calculated nutritional values.

\begin{tabular}{|c|c|c|c|}
\hline Feed ingredients (g/kg) & $\begin{array}{c}\text { Starter } \\
(1-10 \text { days })\end{array}$ & $\begin{array}{c}\text { Grower } \\
\text { (11-24 days) }\end{array}$ & $\begin{array}{c}\text { Finisher } \\
\text { (24-42 days) }\end{array}$ \\
\hline Corn & 58.8 & 59.9 & 65.3 \\
\hline Soybean meal (45\%CP) & 35.6 & 33.6 & 28.3 \\
\hline Dicalcium phosphate & 1.74 & 1.50 & 1.56 \\
\hline Soybean Oil & 1.44 & 2.96 & 2.81 \\
\hline Calcium $\mathrm{CO}_{3}$ & 1.34 & 1.11 & 1.15 \\
\hline Mineral Premix & 0.25 & 0.25 & 0.25 \\
\hline Vitamin Premix & 0.25 & 0.25 & 0.25 \\
\hline DL-methionine (98\%) & 0.24 & 0.16 & 0.14 \\
\hline Common Salt & 0.20 & 0.20 & 0.20 \\
\hline L-Lysine $\mathrm{HCl}(78 \%)$ & 0.15 & - & - \\
\hline Total & 100 & 100 & 100 \\
\hline \multicolumn{4}{|l|}{ Calculated nutritional values } \\
\hline Metabolized energy (kcal/kg) & 2904 & 3024 & 3072 \\
\hline Crude protein (\%) & 21.12 & 20.16 & 18.28 \\
\hline Calcium (\%) & 1.00 & 0.86 & 0.87 \\
\hline Available phosphorus (\%) & 0.48 & 0.43 & 0.43 \\
\hline Digestible lysine (\%) & 1.22 & 1.06 & 0.93 \\
\hline Digestible methionine (\%) & 0.56 & 0.47 & 0.42 \\
\hline Digestible methionine +cystine(\%) & 0.90 & 0.80 & 0.73 \\
\hline Digestible threonine (\%) & 0.78 & 0.75 & 0.67 \\
\hline
\end{tabular}

Dicalcium phosphate contained: $16 \%$ phosphorous and $23 \%$ calcium. avitamin premix per kg of diet: vitamin A (retinol), $2.7 \mathrm{mg} ;$ vitamin D3 (Cholecalciferol), $0.05 \mathrm{mg}$; vitamin $\mathrm{E}$ (tocopheryl acetate), 18 mg; vitamin k3, 2 mg; thiamine 1.8 mg; riboflavin, 6.6 mg; pantothenic acid, 10 mg; pyridoxine, 3 mg; cyanocobalamin, 0.015 mg; niacin, 30 mg; biotin, 0.1 mg; folic acid, 1 mg; choline chloride, 250 mg; Antioxidant 100 mg. ${ }^{b}$ Mineral premix per kg of diet: Fe (FeSO4.7H20, 20.09\% Fe), 50 mg; Mn (MnSO4.H20, 32.49\% Mn), 100 mg; Zn (ZnO, 80.35\% Zn), 100 mg; Cu (CuSO4.5H2O), 10 mg; I (KI, 58\% I), 1 mg; Se (NaSeO3, 45.56\% Se), 0.2 mg.

dissected and $1 \mathrm{~g}$ of cecum contents was collected into falcon containing $10 \mathrm{~mL}$ of physiological saline and glycerin (9 parts saline and 1 part glycerin) and were kept on ice until inoculation and incubation. All samples were diluted 1:10 with normal saline solution and their weight was recorded (Hashemi et al., 2012). Further serial dilutions $\left(10^{-5}\right.$ to $\left.10^{-6}\right)$ were made in normal saline solution and $300 \mathrm{~mL}$ were plated on agar plates. Escherichia coli was quantified on the mac kankey agar (Merck, Darmstadt, Germany, 2013). Plates were incubated for $24 \mathrm{~h}$ at $37^{\circ} \mathrm{C}$. Lactobacillus was counted on the MRS agar (Merck, Darmstadt, Germany, 2013) and Plates were incubated at $37^{\circ} \mathrm{C}$ for 48-72 h (Engberg et al., 2000). Results were expressed as log of colony forming units (CFU) per gram of caecum content (Hashemi et al., 2012).

\section{Intestinal morphometric measurement}

The intestinal morphometric variables, villus height, crypt depth, goblet cell number, epithelial thickness and villus height: crypt depth ratio was evaluated in the duodenum, jejunum and ileum (Langhout et al., 1999). On day 42, 4 male birds from each treatment were killed by decapitation, then, $3 \mathrm{~cm}$ lengths of duodenum (midpoint of the pancreatic loop), jejunum (midpoint of jejunum) and ileum (5 cm after diverticulum vitellinum) were removed for gut morphological measurements. Intestinal samples from each section were immersed in formaldehyde, before fixation in bouin's solution and paraffin embedding. Histological examinations were carried out according to the method of lji et al. (2001). Paraffin sections at $6 \mu \mathrm{m}$ thickness were made from each sample, stained with hematoxylin and eosin, and examined by light microscopy. Villus height, crypt depth, goblet cell number and epithelial thickness were analyzed from each preparation. The length of the intestinal villi and the depth of the intestinal crypt were measured with linear scaled graticule. The number of goblet cells $/ \mu \mathrm{m}^{2}$ area of the villus and crypts was measured by 25 squared graticule.

\section{Statistical analysis}

A completely randomized design (CRD) was employed. Data were analyzed by General Linear Models procedure of Statistical Analysis System (SAS, 2004). Logarithmic (Log 10) transformation was applied for microbial colony forming unit (CFU) data. Duncan's multiple range test were used for comparison of means $(p<0.05)$. 


\section{RESULTS}

\section{Growth Performance}

During the starter period (1-10 days of age), the birds fed $200 \mathrm{mg}$ coriander essential oil/kg diet and the diet with antibiotic had significantly lower feed intake as compared to the other treatments $(p<0.01)$. Birds fed diets containing coriander essential oil at the level of $300 \mathrm{mg} / \mathrm{kg}$ treatment had the highest weight gain and those fed the control treatment had the worst FCR during the starter period $(p<0.01)$. No differences ( $p>0.05)$ in feed intake and weight gain were observed between birds under the different dietary treatments during the grower period (11-24 days of age); however, antibiotic-fed birds presented the lowest FCR during grower period $(p<0.05)$. During the finisher period ( $25-$ 42 days of age), the antibiotic treatment and coriander essential oil at $300 \mathrm{mg} / \mathrm{kg}$ increased feed intake and birds fed the feed with antibiotic presented higher weight gain $(p<0.05)$. During the finisher period, the FCR of birds fed coriander essential oil at levels of 200 and $300 \mathrm{mg} / \mathrm{kg}$ and antibiotic was lower than that of birds in the control treatment $(p<0.05)$. During entire period (1-42 days of age), the highest feed intake and weight gain were observed with the diets containing the antibiotic and coriander essential oil at $300 \mathrm{mg} /$ $\mathrm{kg}(p<0.01)$. Feed conversion ratio of birds in the coriander essential oil and antibiotic treatments was significantly better compared with those in the control treatment $(p<0.01)$, as shown in Table 2 .

\section{Serum biochemistry}

The dietary supplementation with coriander essential oil and antibiotic did not significantly affect cholesterol, low density lipoprotein (LDL), high density lipoprotein $(\mathrm{HDL})$, very low density lipoprotein $(\mathrm{VLDL})$, triglyceride or and glucose serum levels ( $p>0.05)$, as shown in Table 3.

\section{Microbial enumeration}

The dietary supplementation with coriander essential oil did not affect Lactobacillus spp. ( $p>0.05$ ) counts. Lower Escherichia coli counts were observed in the ceca of birds fed coriander essential oil at levels of 200 and $300 \mathrm{mg} / \mathrm{kg}$ and antibiotic compared with the control treatment $(p<0.05)$, as show in Table 4.

\section{Histomorphological measurements}

The antibiotic and coriander essential oil treatments promoted higher villus height and crypt depth in the small intestinal in comparison with control treatment $(p<0.01)$. Coriander essential oil supplementation reduced epithelial thickness and the number of goblet cells in the small intestinal compared with the control treatment $(p<0.0001)$. Lower villus height to crypt depth ratio in duodenum was determined in birds fed coriander essential oil $300 \mathrm{mg} / \mathrm{kg}(p<0.05)$. Coriander essential oil $300 \mathrm{mg} / \mathrm{kg}$ and antibiotic reduced villus height: crypt depth ratio in jejunum and ileum compared with other treatments $(p<0.01)$, as show in Table 5 .

Table 2 - Effect of dietary coriander essential oil and antibiotic on feed intake, weight gain and feed conversion ratio in broiler chickensa

\begin{tabular}{|c|c|c|c|c|c|c|c|}
\hline \multirow[b]{2}{*}{$p$ value } & \multirow[b]{2}{*}{ SEM } & \multirow[b]{2}{*}{ antibiotic } & \multirow[b]{2}{*}{ Control } & \multirow[b]{2}{*}{$300 \mathrm{mg} / \mathrm{kg}$} & \multirow{2}{*}{\multicolumn{2}{|c|}{$\begin{array}{l}\text { Treatments } \\
100 \mathrm{mg} / \mathrm{kg}\end{array}$}} & \multirow{2}{*}{ Item } \\
\hline & & & & & & & \\
\hline & & \multicolumn{6}{|c|}{ Feed intake $(\mathrm{g} / \mathrm{bird} / \mathrm{d})$} \\
\hline 0.003 & 3.51 & $287^{b}$ & $306^{a}$ & $306^{a}$ & $292^{b}$ & $302^{a}$ & 1-10 days \\
\hline 0.08 & 16.09 & 1332 & 1317 & 1370 & 1331 & 1300 & $11-24$ days \\
\hline 0.02 & 23.04 & $2480^{a}$ & $2437^{\mathrm{ab}}$ & $2396^{b}$ & $2386^{b}$ & $2363^{b}$ & 25-42days \\
\hline \multirow[t]{2}{*}{0.002} & 23.15 & $4125^{a}$ & $4082^{a b}$ & $4082^{a b}$ & $4013^{b c}$ & $3973^{c}$ & $1-42$ days \\
\hline & & & \multicolumn{5}{|c|}{ Weight gain (g/bird/d) } \\
\hline 0.002 & 5.39 & $204^{\mathrm{ab}}$ & $173^{c}$ & $208^{a}$ & $189^{b}$ & $196^{\mathrm{ab}}$ & 1-10 days \\
\hline 0.11 & 14.14 & 799 & 749 & 774 & 755 & 753 & 11-24 days \\
\hline 0.01 & 25.36 & $1304^{a}$ & $1200^{b}$ & $1321^{a}$ & $1269^{a b}$ & $1220^{b}$ & 25-42 days \\
\hline \multirow[t]{2}{*}{0.002} & 31.43 & $2311^{a}$ & $2122^{b}$ & $2309^{a}$ & $2219^{a b}$ & $2169^{b}$ & 1-42 days \\
\hline & & & & \multicolumn{4}{|c|}{ feed conversion ratio (feed/gain) } \\
\hline 0.0004 & 0.04 & $1.40^{b}$ & $1.78^{\mathrm{a}}$ & $1.43^{b}$ & $1.54^{b}$ & $1.54^{b}$ & 1-10 days \\
\hline 0.03 & 0.02 & $1.66^{b}$ & $1.75^{\mathrm{a}}$ & $1.77^{a}$ & $1.76^{a}$ & $1.72^{\mathrm{ab}}$ & 11-24 days \\
\hline 0.01 & 0.03 & $1.90^{b}$ & $2.03^{a}$ & $1.81^{b}$ & $1.86^{b}$ & $1.94^{\mathrm{ab}}$ & 25-42days \\
\hline 0.001 & 0.02 & $1.78^{b}$ & $1.92^{\mathrm{a}}$ & $1.76^{b}$ & $1.80^{b}$ & $1.83^{b}$ & 1-42 days \\
\hline
\end{tabular}

a Results are given as means of treatments

$a, b, c$ Means within a row with different superscripts are significantly different $(p<0.05)$

SEM: standard error of means. 
Table3 - Effect of dietary coriander essential oil and antibiotic on on serum biochemical parameters of broilers at 42 days of agea

\begin{tabular}{|c|c|c|c|c|c|c|c|}
\hline \multirow[b]{2}{*}{$p$ value } & \multirow[b]{2}{*}{ SEM } & \multirow[b]{2}{*}{ Antibiotic } & \multirow[b]{2}{*}{ Control } & \multirow[b]{2}{*}{$300 \mathrm{mg} / \mathrm{kg}$} & \multicolumn{2}{|c|}{ Treatments } & \multirow{2}{*}{ Item } \\
\hline & & & & & $200 \mathrm{mg} / \mathrm{kg}$ & $100 \mathrm{mg} / \mathrm{kg}$ & \\
\hline 0.75 & 12.25 & 113.7 & 128.7 & 120.7 & 130 & 111.2 & Cholesterol (mg/dL) \\
\hline 0.12 & 13.75 & 82 & 138.2 & 114 & 118.7 & 111.7 & Triglyceride(mg/dl) \\
\hline 0.54 & 22.88 & 240.2 & 280 & 234.5 & 229.2 & 237 & glucose(mg/dl) \\
\hline 0.88 & 4.69 & 52 & 54.75 & 54.25 & 52.75 & 48.50 & ${ }^{1} \mathrm{HDL}(\mathrm{mg} / \mathrm{dl})$ \\
\hline 0.94 & 11.61 & 45.50 & 46.75 & 43.75 & 54 & 40.50 & ${ }^{2} \mathrm{LDL}(\mathrm{mg} / \mathrm{dl})$ \\
\hline 0.13 & 2.72 & 16.25 & 27.25 & 22.75 & 23.25 & 22.25 & ${ }^{3} \mathrm{VLDL}(\mathrm{mg} / \mathrm{dl})$ \\
\hline
\end{tabular}

a Results are given as means of treatments

${ }^{1}$ High density lipoprotein, ${ }^{2}$ Low density lipoprotein, ${ }^{3}$ Very low density lipoprotein

$a, b, c$ Means within a row with different superscripts are significantly different $(p<0.05)$

SEM: standard error of means.

Table 4 - The effect of dietary coriander essential oil supplementation on Escherichia coli and Lactobacilli numbers in the cecum contents of broilers at 42 days of age.

\begin{tabular}{|c|c|c|c|c|c|c|c|}
\hline \multirow[b]{2}{*}{ p-value } & \multirow[b]{2}{*}{ SEM } & \multirow[b]{2}{*}{ antibiotic } & \multirow[b]{2}{*}{ control } & \multicolumn{3}{|c|}{ Treatment } & \multirow{2}{*}{ Item } \\
\hline & & & & $300 \mathrm{mg} / \mathrm{kg}$ & $200 \mathrm{mg} / \mathrm{kg}$ & $100 \mathrm{mg} / \mathrm{kg}$ & \\
\hline 0.88 & 0.03 & 4.465 & 4.462 & 4.507 & 4.462 & 4.467 & Lactobacillus(log cfu g-1) \\
\hline 0.02 & 0.04 & $4.23^{b}$ & $4.44^{\mathrm{a}}$ & $4.25^{b}$ & $4.29^{b}$ & $4.36^{a b}$ & Escherichia coli(log cfu g-1) \\
\hline
\end{tabular}

$a, b, c$ Means within a row with different superscripts are significantly different $(p<0.05)$

SEM: standard error of means.

log cfu g-1: log of colony forming units per gram of caecum content

Table5 - Effect of dietary treatments on the intestinal morphology of birds on 42 days of age.

\begin{tabular}{|c|c|c|c|c|c|c|c|}
\hline \multirow[b]{2}{*}{$\mathrm{p}$-value } & \multicolumn{6}{|c|}{ Treatment } & \multirow[t]{2}{*}{ Item } \\
\hline & SEM & antibiotic & control & $300 \mathrm{mg} / \mathrm{kg}$ & $200 \mathrm{mg} / \mathrm{kg}$ & $100 \mathrm{mg} / \mathrm{kg}$ & \\
\hline & & & & & & \multicolumn{2}{|c|}{ Villus height $(\mu \mathrm{m})$} \\
\hline 0.0001 & 15.14 & $1912.40^{a}$ & $1758.76^{c}$ & $1805.20^{b}$ & $1810.00^{b}$ & $1798.00^{\mathrm{bc}}$ & Duodenum \\
\hline 0.0001 & 3.74 & $876.60^{a}$ & $849^{d}$ & $872.20^{\mathrm{ab}}$ & $866.20^{\mathrm{bc}}$ & $858.00^{\mathrm{cd}}$ & Jejunum \\
\hline \multirow[t]{2}{*}{0.005} & 13.95 & $829.40^{a}$ & $756.60^{c}$ & $782.60^{\mathrm{bc}}$ & $799.20^{\mathrm{ab}}$ & $770.40^{\mathrm{bc}}$ & Ileum \\
\hline & & & & & & \multicolumn{2}{|c|}{ Crypt depth $(\mu \mathrm{m})$} \\
\hline 0.004 & 2.67 & $157.60^{\mathrm{ab}}$ & $147.80^{c}$ & $161.60^{\mathrm{a}}$ & $157.20^{\mathrm{ab}}$ & $150.80^{\mathrm{bc}}$ & Duodenum \\
\hline$<0.0001$ & 1.93 & $133.40^{\mathrm{a}}$ & $107.60^{d}$ & $116.00^{b}$ & $114.20^{\mathrm{bc}}$ & $109.40^{\text {cd }}$ & Jejunum \\
\hline$<0.0001$ & 3.33 & $129.80^{\mathrm{a}}$ & $97.00^{d}$ & $118.40^{b}$ & $116.20^{b}$ & $106.40^{c}$ & Ileum \\
\hline \multicolumn{8}{|c|}{ Epithelial thickness $(\mu \mathrm{m})$} \\
\hline 0.0001 & 1.5 & $38.20^{c}$ & $48.40^{\mathrm{a}}$ & $34.80^{c}$ & $38.80^{\mathrm{bc}}$ & $42.60^{b}$ & Duodenum \\
\hline 0.0001 & 1.34 & $35.40^{\mathrm{a}}$ & $39.00^{\mathrm{a}}$ & $29.00^{b}$ & $30.40^{b}$ & $36.00^{\mathrm{a}}$ & Jejunum \\
\hline \multirow[t]{2}{*}{$<0.0001$} & 1.67 & $29.20^{b}$ & $35.00^{\mathrm{a}}$ & $21.60^{c}$ & $23.40^{c}$ & $26.20^{b c}$ & Ileum \\
\hline & & & & & & & Goblet cells \\
\hline 0.0001 & 0.5 & $8.80^{\mathrm{bc}}$ & $10.60^{\mathrm{a}}$ & $6.20^{d}$ & $7.80^{\circ}$ & $9.20^{\mathrm{b}}$ & Duodenum \\
\hline 0.0001 & 0.46 & $9^{a b}$ & $10.20^{\mathrm{a}}$ & $7.00^{c}$ & $7.20^{c}$ & $8.00^{\mathrm{bc}}$ & Jejunum \\
\hline \multirow[t]{2}{*}{$<0.0001$} & 0.46 & $7.60^{c}$ & $10.80^{\mathrm{a}}$ & $6.40^{c}$ & $7.00^{c}$ & $9.00^{b}$ & lleum \\
\hline & & & & & \multicolumn{3}{|c|}{ Villus height: Crypt depth } \\
\hline 0.036 & 0.24 & $12.15^{\mathrm{a}}$ & $11.91^{\mathrm{a}}$ & $11.18^{b}$ & $11.53^{\mathrm{ab}}$ & $11.94^{\mathrm{a}}$ & Duodenum \\
\hline$<0.0001$ & 0.12 & $6.58^{c}$ & $7.90^{\mathrm{a}}$ & $7.53^{b}$ & $7.59^{\mathrm{ab}}$ & $7.85^{\mathrm{ab}}$ & Jejunum \\
\hline 0.006 & 0.29 & $6.40^{c}$ & $7.88^{\mathrm{a}}$ & $6.61^{\mathrm{bc}}$ & $6.89^{\mathrm{bc}}$ & $7.26^{\mathrm{ab}}$ & Ileum \\
\hline
\end{tabular}

${ }^{a}$ Results are given as means of treatments

$a, b, c$ Means within a row with different superscripts are significantly different $(p<0.05)$

SEM: standard error of means. 
The intestinal villi were narrow and finger-shaped and none of the dietary treatments caused any histopathological changes in the intestinal mucosa (Figures 1 and 2).

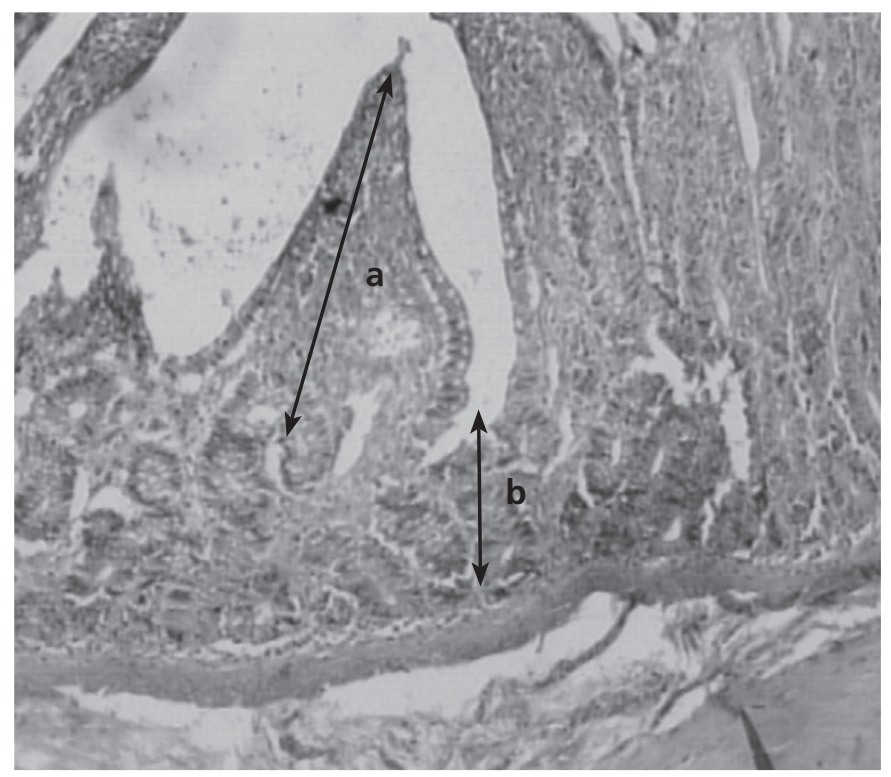

Figure 1: Photomicrograph of the cross section of jejunum full thickness of a control broiler

(a: indicating villus height and b: indicating crypt depth as measured) $\mathrm{H}$ and E X100 (Scale Bar $=500 \mu \mathrm{m}$ )

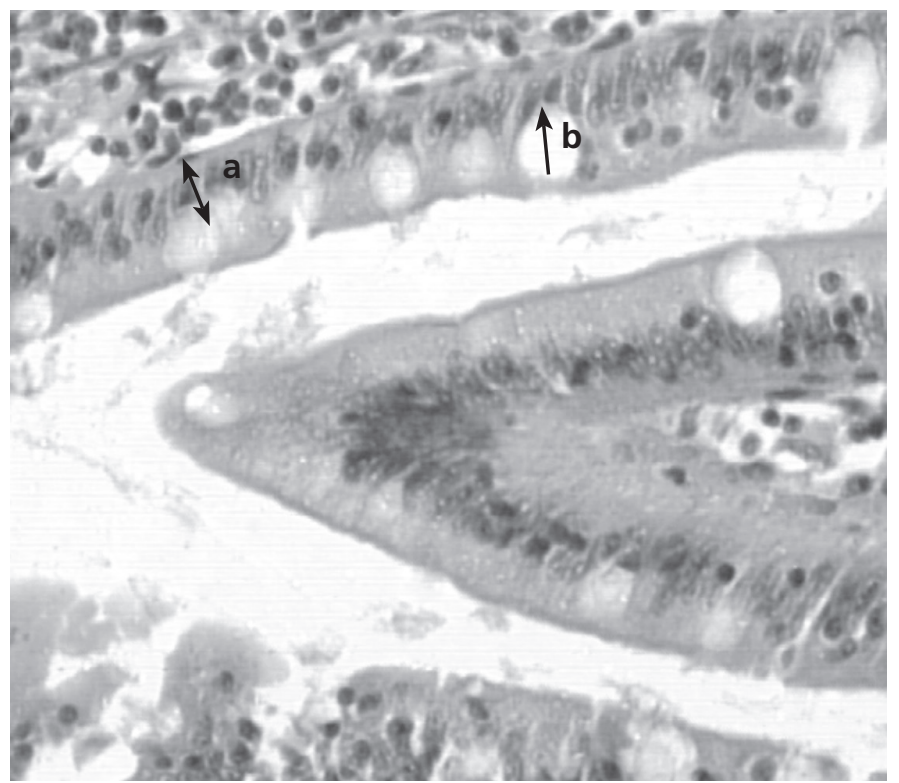

Figure 2: Photomicrograph of the cross section of jejunum full thickness of a control animal (a: indicating Epithelial thickness and b: indicating Goblet cell as measured) $\mathrm{H}$ and $\mathrm{E} X 400($ Scale Bar $=500 \mu \mathrm{m})$

\section{DISCUSSION}

\section{Growth performance}

In present study, coriander oil and antibiotic improved broiler performance, as shown by the higher growth rates and better FCR compared with the control birds.
The improvement in FCR was a result of differences in feed intake, and possibly due to higher feed digestibility. Lee et al. (2004) suggested that essential oil may increase feed intake in broilers mainly due to their pleasant odor and flavor. In addition, Çabuk et al. (2003) observed that the main component of coriander oil, linalool, promoted increase in broiler villi height, and therefore, may enhance the activity of digestive enzymes, resulting in higher nutrient absorption, better feed conversion ratio, and greater growth rate. In agreement with these results, Hernandez et al. (2004) reported that the supplementation of essential oils improved apparent total tract and ileal digestibility of nutrients. Similarly, Ramakrishna et al. (2003) observed that the effectiveness of pancreatic lipase and amylase increased with the dietary supplementation of essential oils, and Hernandez et al. (2004) showed high production of digestive enzymes and better feed utilization due to enhanced liver functions in broilers fed essential oils.

\section{Serum traits}

In present study, coriander oil and antibiotic dietary supplementation did not influence blood biochemical parameters of broilers. Najafi \& Torki (2010) indicated that dietary supplementation with essential oils (thyme, cinnamon and clove) did not affect cholesterol or HDL level in broilers. Hong et al. (2012) showed that broilers supplemented with essential oil (oregano, anise and citrus peel) had higher HDL and lower VLDL levels compared with the controls, while no effect was observed on LDL concentrations.

The decrease in cholesterol levels may be due to an inhibition of the hepatic 3-hydroxy-3-methylglutaryl coenzyme A (HMGCoA) reductase activity, which is a key regulatory enzyme in cholesterol synthesis (Lee et al., 2004). Case et al. (1995) reported reduced blood triglyceride levels in Leghorn chickens supplemented with 150 ppm ether thymol extract, probably due to the active ingredients in these supplements that may reduce the activity of lipolysis enzymes, thereby reducing reduce hepatic fatty acid synthesis.

Hong et al. (2012) showed that there were no clear trends for the response of blood lipoproteins to essential oil treatments. It was reported that coriander enhances fecal bile acid and natural sterols, which resulted in lowering serum cholesterol.

\section{Gut microbiota}

It is clear that modulating gut microbiota can positively influence the performance of birds. In the present study, Lactobacillus counts were no effected 
( $p>0.05$ ) by the treatments, but Escherichia coli counts were significantly reduced in the birds fed the diets with coriander essential oil and antibiotic compared with those receiving the control diet. It was previously shown that linalool inhibited pathogenic microorganisms in the digestive system (Çabuk et al., 2003). The reasons for such improvement are most likely associated with the reduction of Escherichia coli load in the gut (Lee et al., 2004). The improvement in broiler performance observed in the present study when coriander essential oil was added to the diet may not only be a result of the improvement in the microbial community structure, but could also be related to the microbial metabolites that affect the nutritional status of animals as well as GIT function and health. Delaquis et al. (2002) reported that essential oils derived from coriander seeds negatively affected gram-negative bacteria and Saccharomycescerevisiae. Similarly, Çabuk et al. (2003) reported that linalool negatively affected Escherichia coli, Pseudomonasaeruginosa, Salmonella typhimurium, Staphylococcus aureus, Clostridium botulinum and Clostridium perfringens intestinal populations. Silva et al. (2011) evaluated the antibacterial action of coriander essential oil against gram-positive and gram-negative bacteria using flow cytometry and suggested that the primary mechanism of action of coriander essential oil is membrane damage. In accordance with our study, Cross et al. (2007) and Kirkpinar et al. (2011) showed that supplementation of some essential oils (thyme, oregano, marjoram, rosemary, or yarrow) had no effect on lactic acid bacteria of broiler. In their study, Delaquis et al. (2002) argued that the higher lactic acid bacteria to coliform ratio found when coriander oil was fed may have been due to stomach $\mathrm{pH}$ reduction, as they observed that the gastric $\mathrm{pH}$ for the treatments coriander oil was substantially lower than the control diet. Lower gastric $\mathrm{pH}$ would enhance the barrier function of the stomach towards acid susceptible bacteria like coliforms and favor the growth of acid tolerant bacteria like lactic acid bacteria, a phenomenon that is observed more caudally in the small intestine. Coriander oil increases the activity of digestive enzymes, and therefore, enhances nutrient digestibility and improves the regulation and stabilization of the gut microbiota. Tucker (2002) argues that the inactivation of $C$. perfringens toxins by digestive enzymes, such as trypsin, could also explain why the colonization of these bacteria was reduced in the GIT of broilers fed essential oils. Ouwehand et al. (2010) found that beneficial microbes, such as lactobacilli and Bifidobacteria, were less sensitive to the antimicrobial effect of essential oils than potentially pathogenic bacteria, such as E. coli, C. perfringens and
Salmonella. Also, Ghazanfari et al. (2014) found that inclusion of myrtle essential oil in broiler diets reduced Escherichia coli counts and increased Lactobacillus counts in the cecum $(p<0.001)$.

\section{Gut morphology}

Mucosa status and their microscopic structure may be good indicators of the response of the intestinal tract to active substances present in feeds and in the intestinal content (Viveros et al., 2011). Short villi and deep crypts may lead to poor nutrient absorption, increased toxin secretion in the gastrointestinal tract, and worse performance (Xu et al., 2003). In contrast, increases in villus height and villus height: crypt depth ratio are directly correlated with increased epithelial cell turnover (Fan et al., 1997), and longer villi are associated with activated cell mitosis (Samanya \& Yamauchi, 2002). It is assumed that increased villus height is paralleled by enhanced digestive and absorptive functions of the intestine due to larger absorptive surface area and higher expression of brush border enzymes and nutrient transport systems (Pluske et al., 1996). In the present study, the supplementation of broilers with coriander oil increased villus height, crypt depth, and decreased the number of goblet cells and epithelial thickness in the small intestine $(p<0.01)$. The histomorphological changes in the intestine of broilers reported in the present study provide new information regarding the potential use of coriander oil in broiler feeds. The concentrations of amylase in broiler intestine increased after the dietary supplementation with coriander oil (Çabuk et al., 2003). Also, Çabuk et al. (2003) found that longer villi were induced by dietary amylase. The results of this study showed that the number of goblet cells and epithelial thickness of birds receiving antibiotic and coriander oil supplementation were lower compared with the control group $(p<0.001)$.

\section{CONCLUSION}

In conclusion, the dietary addition of coriander oil improved feed intake, growth rate and feed conversion ratio of broilers. The dietary supplementation of coriander oil and antibiotic did not significantly affected blood biochemical parameters of broilers, and also resulted in the positive modulation of microbial populations measured in the cecum, as shown by reduced Escherichia coli counts. Furthermore, the dietary supplementation of both coriander oil and antibiotic resulted in an increase villus height and crypt depth and decreased epithelial thickness and number of goblet cells in the intestinal mucosa of 
broilers. These results of the present study suggest that coriander oil may be a suitable alternative to antibiotics for improving broiler performance.

\section{ACKNOWLEDGEMENT}

The authors would like to acknowledge the financial support of University of Tehran, Aburaihan campus for this research under grant number 27341/07.

\section{REFERENCES}

Burdock GA, Carabin IG. Safety assessment of coriander (Coriandrum sativum L.) essential oil as a food ingredient. Food and Chemical Toxicology 2009;47:22-34.

Çabuk M, Alcicek A, Bozkurt M, Imre N. Antimicrobial properties of the essential oils isolated from aromatic plants and using possibility as alternative feed additives. Proceedings of the 2 nd National Animal Nutrition Congress; 2003 Sep 8-20; Konya. Turquia. p.184-187.

Case GL, He L, Mo H, Elson CE. Induction of geranyl pyrophosphate pyrophosphatase activity by cholesterol-suppressive isoprenoids. Journal of Lipid Research 1995;30:357-359.

Cross DE, Mcdevith RM, Hillman K, Acamovic T. The effect of herbs and their associated essential oils on performance, digestibilities and gut microflora in chickens 7 to $28 \mathrm{~d}$ of age. British Poultry Science 2007;4:496-506

Delaquis PJ, Stanich K, Girard B, Mazza G. Antimicrobial activity of individual and mixed fractions of dill, cilantro, coriander and eucalyptus essential oils. International Journal of Food and Microbiology 2002;74:101-109.

Engberg RM, Hedemann MS, Jensen BB, Lesser TD. Effect of zinc bacitracin and salinomycin on intestinal microflora and performance of broilers. Poultry Science 2000;79:1311-1319.

Ertas ON, Guler T, Ciftci M, Dalkilic B, Simsek G. The effect of an essential oil mix derived from oregano, clove and anise on broiler performance. International Journal of Poultry Science 2005;4:879-884.

Fan Y, Croom J, Christensen V, Blank B, Bird A, Daniel L, et al. Jejunal glucose uptake and oxygenconsumption in turkey poults selected for rapid growth. Poultry Science 1997;76:1738-1745.

Ghazanfari S, Adib Moradi, M, Mahmoodi Bardzardi M. Intestinal morphology and microbiology of broiler chicken fed diets containing myrtle (myrtus communis) essential oil supplementation. Iranian Journal of Applied Animal Science 2014;4(3):549-554.

Gholamali J, Maleki M, Sirus S. Effect of walnut leaf, coriander and pomegranate on blood glucose and histopathology of pancreas of alloxan induced diabetic rats. African Journal of Traditional, Complementary and Alternative Medicines 2007;4(3):299-305.

Hammer KA, Carson CF, Riley TV. Antimicrobial activity of essential oils and other plants extracts. Journal of Apply Microbiology 1999;86:985-990.

Hashemi SR, Zulkifli I, Davoodi H, Zunita Z, Ebrahimi M. Growth performance, intestinal microflora, plasma fatty acid profile in broiler chickens fed herbal plant (Euphorbia hirta) and mix of acidifiers. Animal Feed Science and Technology 2012;178:167-174.

Hernandez F, Madrid J, Garcia V, Orengo J, Megias MD. Influence of two plant extracts on broiler performance, digestibility, and digestive organ size. Poultry Science 2004;83:169-174.

Hong JC, Steine T, Aufy A, Lien TF. Effects of supplemental essential oil on growth performance, lipid metabolites and immunity, intestinal characteristics, microbiota and carcass traits in broilers. Livestock Science 2012;144:253-262.

Iji PA, Saki AA, Tivey DR. Intestinal development and body growth of broiler chicks on diets supplemented with non-starch polysaccharides. Animal Feed Science and Technology 2001; 89:175-188.
Jamroz D, Orda I, Kamel C, Wiliczkiewicz A, Wertelecki T, Scorupinska J. The influence of phytogenic extracts on performance, nutrient digestibility, carcass characteristics, and gut microbial status in broiler chickens. Journal Animal Feed Science and Technology 2003;12:583-596.

Jamroz D, Wiliczkiewicz A, Wertelecki T, Orda J, Scorupinska J. Use of active substances of plant origin in chicken diets based on maize and domestic grains. British Poultry Science 2005;46:485-493.

Kirkpinar F, Bora Ünlu H, Özdemir G. Effects of oregano and garlic essential oils on performance, carcase, organ and blood characteristics and intestinal microflora of broilers. Livestock Science 2011;137:219-225.

Langhout DJ, Schutte JB, Van LP, Wiebenga J, Tam-Minga S. Effect of dietary high and low methylated citruspectin on the activity of the ileal microflora and morphologyof the small intestinal wall of broiler chickens. British Poultry Science 1999;40:340-347.

Lee KW, Everts H, Beynen AC. Essential oils in broiler nutrition. International Journal of Poultry Science 2004;3:738-752.

Lee KW, Everts H, Kappert HJ, Frehner M, Losa R, Beynen AC. Effects of dietary essential oil components on growth performance, digestive enzymes and lipid metabolism in female broiler chickens. British Poultry Science 2003;44:450-457.

Mountzouris KC, Tsistsikos P, Kalamara E, Nitsh S, Schatz-Mayr G, Fegeros K. Evaluation of the efficacy of a probiotic containing Lactobacillus, Bifidobacterium, Enterococcus and Pediococcus strains in promoting broiler performance andmodualting cecal microflora composition and metabolic activities. Poultry Science 2007;86:309-317.

Najafi P, Torki M. Performance, blood metabolites and immunocompetaence of broiler chicks fed diets included essential oils of medicinal herbs. Journal of Animal and Veterinary Advances 2010;9:1164-1168.

Ouwehand AC, Tiihonen K, Kettunen H, Peuranen S, Schulze H, Rautonen $\mathrm{N}$. In vitro effects of essential oils on potential pathogens and beneficial members of the normal microbiota. Veterinarni Medicina 2010;55:71 78.

Pluske JR, Tompson MJ, Atwood CS, Bird PH, Williams IH, Hartmann PE. Maintenance of villus heightand crypt depth, and enhancement of disaccharide digestion andmonosaccharide absorption, in piglets fed on cows' whole milkafter weaning. British Journal Nutrition 1996;76:409-422

Ramakrishna RR, Platel K, Srinivasan K. In vitro influence of species and spice-active principles on digestive enzymes of rat pancreas and small intestine. Nahrung 2003;47:408-412.

Samanya M, Yamauchi K. Histological alterations ofintestinal villi in chickens fed dried Bacillus subtilisvar natto. Comparative Biochemistry Physiology 2002;133:95-104.

SAS. SAS user's guide statistics. Version 8. Cary, NC, USA; 2004

Silva F, Ferreira S, Duarte A, Mendonça ADI, Domingues FC. Antifungal activity of Coriandrum sativum essential oil, its mode of action against Candida species and potential synergism with amphotericin B. Phytomedine 2011;20:35-40.

Toghyani M, Gheisari A, Ghalamkari G, Eghbalsaied SH. Evaluation of cinnamon and garlic as antibiotic growth promoter substitutions on performance, immune responses, serum biochemical and haematological parameters in broiler chicks. Livestock Science 2011;138:167-173

Tucker L. Botanical broilers: Plant extracts to maintain poultry performance. Feed International 2002;23:26-29.

Viveros A, Chamorro S, Pizarro M, Arija I, Centeno C, Brenes A. Effects of dietary polyphenol-rich grape products on intestinal microflora and gut morphology in broiler chicks. Poultry Science 2011;90:566-578.

Williams P, Losa R. The use of essential oils and their compounds in poultry nutrition. World Poultry Science Journal 2001;17:14-15.

Xu ZR, Hu CH, Xia MS, Zhan XA, Wang MQ. Effects of dietary fructooligosaccharides on digestive enzyme activities, intestinal microflora and morphology of male broilers. Poultry Science 2003;82:1030-1036. 